\title{
Towards a Critical Sociology of Children's Leisure
}

\author{
Utsa Mukherjee ${ }^{1}$ (i)
}

Received: 22 April 2020 / Accepted: 4 June 2020 /Published online: 19 June 2020

(C) The Author(s) 2020

\begin{abstract}
In this article, I contend that the sociology of leisure in particular and leisure studies in general has been shaped by adult-centric assumptions which have marginalized children's perspectives on and experiences of leisure within theory building exercises. Consequently, leisure researchers who do empirical work on children's leisure have largely eschewed critical debates about children's agency, social positioning and lived citizenship among others that have been developed by the 'new' sociology of childhood. Failure to build bridges with other areas of scholarship such as sociological childhood studies, has intensified the intellectual isolation of leisure research. Here, I propose a sustained dialogue between leisure studies and childhood studies which will not only widen the intellectual breadth of leisure theory and make it more inclusive, but also enable leisure studies to have an impact on the new social studies of childhood. In illustrating what such a collaboration might entail, I outline a conceptual schema of three interlocking genres of children's leisure - namely organized, family and casual leisure - based on existing studies conducted by researchers in leisure, childhood and family studies that offer a roadmap for the development of a new critical sociology of children's leisure.
\end{abstract}

Keywords Children's leisure - Leisure theory · Sociology of childhood · Adult-centrism · Children's agency

\section{Introduction}

The sociology of leisure has come of age in recent decades with a rich armoury of theoretical, empirical, and methodological insights into everyday forms of leisure. The foundations of these sociological understandings of leisure can be traced to the historical emergence of sociology itself; ideas which were later distilled and institutionalized through the inauguration of leisure studies as a field of research in the 1970s

Utsa Mukherjee

u.mukherjee@bbk.ac.uk

1 Birkbeck University of London, London, UK 
(Snape, 2020; Roberts, 2013). Since then, sociological scholarship on leisure has proliferated along multiple axes - asking importance questions about the social processes, institutions and actors involved in leisure and using leisure as a lens to understand wider social formations. At the same time the impact of leisure research on mainstream sociology or other social sciences has been rather thin on the ground, prompting scholars to rethink research agendas and advocate the need for establishing links with other fields of research to enhance visibility and impact of leisure scholarship (Stebbins, 2018; Fletcher et al., 2017; Shaw, 2000; Deem, 1999). Drawing on these sociological strands of leisure research, in this article I argue that leisure theory is adultcentric in its foundational assumptions and therefore studies on children's leisure undertaken by leisure sociologists have failed to enter into sustained dialogue with the sociology of childhood. Establishing such links can not only widen our understanding of leisure forms and practices, but also lend greater visibility to leisure scholars outside the realm of leisure studies. To illuminate these arguments, this article has three primary objectives. First, I offer a critique of the adult-centrism that marks the contemporary arc of debate within the sub-disciplinary area of sociology of leisure in particular and the interdisciplinary field of leisure studies in general. Second, I assess the place of children's leisure within the corpus of leisure scholarship and demonstrate how studies on children's leisure conducted by leisure scholars have eschewed key debates about children's agency, generational order, and power relations prevalent within the sociology of childhood. These I argue are missed opportunities for enriching our understanding of children's leisure and of influencing the works of childhood scholars working on leisure. One way this lack can be addressed, I contend, is through a disruptive collaboration (Fox, 2000) between the sociology of leisure and the 'new' sociology of childhood. Third, I outline a conceptual map for studying children's leisure in the global north that is based on the cross-pollination of ideas between leisure studies and childhood studies. The article closes with a reflection on the critical sociology of children's leisure and its wider applications for leisure theory and research. By breaking new grounds within leisure studies, through this intervension I hope to set the ball rolling for a truly critical and engaged sociology of children's leisure that is attuned to the multiple lived realities of contemporary childhoods and that of leisure; in the processes enriching both leisure studies and childhood studies.

\subsection{Adult-Centrism and the Sociology of Leisure}

Sociology of leisure, like any other area of knowledge production, is governed by assumptions about the object of its study and the methodological tools appropriate for its analysis. These underlying assumptions give leisure sociology a sense of direction whilst also setting its boundaries. As Kelly (1974) points out, leisure scholars need to reflect upon the nature of these assumptions to forge the way forward for leisure research. When it comes to such disciplinary assumptions in sociology at large, Gouldner (1971) argues that they are of two kinds: explicitly formulated assumptions and those that are unlabelled and unpostulated. The latter remains at the background of the researchers' attention and becomes silent partners in the building of social theories. Therefore, it is important for leisure scholars to not only acknowledge the explicitly labelled assumptions but to also draw out those background assumptions which inform our direction of travel as a field, albeit silently. In unpacking these disciplinary 
assumptions, leisure scholars have thus far reflected upon the way leisure is defined within research agendas and raised questions about whose leisure gets represented within the academic literature (Juniu and Henderson, 2001; Allison, 2000). The definitional debate around leisure has largely been encased within the leisure paradox of freedom and constraint (Coalter, 1989) - which often translates into two opposing camps of leisure theories, the liberal view of leisure with its notion of freedom and the critical approach that identifies structural constraints and pays attention to the role of leisure in (re)producing social inequalities (see Spracklen, 2009). In this critical vein, gender (Henderson, 2013), sexuality (Boulila, 2019), ageing (Liechty and Genoe, 2013), ability (Brittain, Biscaia and Gérard, 2020), social class (Roberts, 2015) and race and ethnicity (Hylton, 2010) have over the years become prominent lenses for sociologists of leisure to draw out the ways in which power relations mediated by these structures play out within leisure geographies and how they constrain the leisure experiences of some while enabling those of others - in the processes entrenching existing disparities. Of course, there is still a long way to go for leisure studies in terms of fully engaging with questions of marginalization and social justice, but conversations in that direction have now begun in earnest. Whilst race, class, gender, ageing and working patterns have been recognized as some of the central axial constructs of western leisure (Rojek, Shaw and Veal, 2006b), there is a conspicuous absence in leisure theories of child-centred lenses and an implied disavowal of age-based power hierarchies in which children and their leisure are embedded. None of the leisure research handbooks or major publications in leisure theory (Blackshaw, 2013; Rojek, 2005, 2010; Rojek, Shaw and Veal, 2006a; Spracklen, 2009; Roberts, 2006) contain a single chapter outlining a child-centred approach to leisure; if children do appear they do so as an appendix to questions around family and women or as an illustration of unidirectional socialization. This is, however, not the case with youth - whose leisure cultures have been central to the enterprise of leisure studies from its inception (Bennett, 2013; Roberts, 1983). In other words, leisure sociology has for the most part ignored school-age children while defining and theorizing leisure and as a result adultcentric biases of leisure theory have for long been left unacknowledged and unchallenged. This is not to claim that leisure researchers have never studied children's leisure, for they have (Fowlie, Eime and Griffiths, 2020; Fader, Legg and Ross, 2019; Asakitikpi, Adeyemi and Nnamani, 2018; Shannon, 2016, 2006; Mjaavatn, 2016; Rhoden, Hunter-Jones and Miller, 2016; Karsten, Kamphuis and Remeijnse, 2015; Jeanes and Magee, 2012; Haglund and Anderson, 2009; Gill and Persson, 2008; Shaw, Havitz and Delemere, 2008; Shannon and Shaw, 2008; Macdonald et al., 2005; Yuen, Pedlar and Mannell, 2005; Yuen, 2004; Zabriskie and McCormick, 2003). But these studies are riddled with conceptual limitations. Firstly, despite amplifying children's voices within leisure studies, these scholars have not drawn upon debates in childhood studies - for example none of them mention children's agency - and thereby missed the opportunity of influencing childhood researchers. Secondly, these isolated empirical projects have not been channelled into systematic theory building endeavours and till date the mainstream of leisure theory has been largely unaffected by children's leisure as evidenced by their conspicuous absence from major leisure theory monographs and research handbooks. Thirdly, leisure scholars working with children publish their works exclusively in specialist leisure journals and do not engage with major childhood studies journals of which there are now several (for example, Childhood, 
Children's Geographies, Journal of Childhood Studies, Children and Society and Global Studies of Childhood). These trends run the risk of intellectual isolation that commentators (Samdahl and Kelly, 1999; also see Parr and Schmalz, 2019) have consistently warned leisure researchers against.

The adult-centrism of leisure sociology, far from being an exception, is symptomatic of the wider social sciences. Blatterer (2007) argues that adulthood has always been the take-for-granted status of social actors in the vast majority of social enquiries while at the same time the category of adulthood itself has remained uncontested. Here, he echoes Elias' (1978, pp. 248) contention that the ideal actor in sociology "was never a child and seemingly came into the world an adult". Blatterer (2007) goes on to point out that in every sphere of sociological studies - from the analysis of global process to the micro-level understanding of everyday life - the social actor whether understood as an individual or as a system has always been the embodiment of adulthood. It has been argued that this adult-centrism and the resultant marginalization of children within mainstream sociology reflects the subordinate status of children within wider society (Mayall, 1998; Alanen, 1988). Of course, the status of children within society in general and their representation within social accounts in particular have been constituted by historical processes. The French historian Ariès (1962) has shown that the modern idea of childhood emerged in the West in a unique way which quarantined children from the adult world of work and economic responsibility in sharp contrast to the active role children played in medieval European society. Children were thus segregated from the adult world and modern western childhood became increasingly familialized and scholarized. This social quarantine of children has been mirrored in the exclusion of children from sociological research and data collection (Scott, 2000; Qvortrup, 1987). Even when children do appear in branches of social theory such as economic and political philosophy, the academic debate - in Gordon's (2008, pp. 165) words - "ranges from the mildly embarrassing to the downright ridiculous". In order for leisure sociology to move beyond its adult centrism, it has to address its intellectual isolation (Samdahl and Kelly, 1999; Parr and Schmalz, 2019) from other relevant bodies of literature - in this case the sociology of childhood - and thereby refashion its conceptual and methodological arsenal.

\subsection{The Sociology of Leisure and the 'New' Sociology of Childhood - A Disruptive Collaboration}

Children are not entirely new to sociology but until late 1980s there was a "conceptual homelessness of childhood" within the discipline (Qvortrup, 2007, pp. 395) with a great paucity of literature about how real children lived their lives and contributed to their social milieu (Alanen, 1988; Ambert, 1986). In fact, sociological writings have historically mentioned children only in reference to their unidirectional socialization, which was underpinned by the idea that childhood is a transitional life-stage/period and children were of interest to sociology only insofar as they revealed clues about their future adulthood (Alanen, 1992; Mayall, 2013). In other words, children were not of interest to sociology in the here and now and they were not seen as social actors in their own right but merely as adults-in-the making. These ideas about children as apprenticeadults and their place in society translated into methodological practices wherein children were seen but never heard - primarily within the sociologies of family and 
education. Information about children's lives therefore came from adults, such as parents and teachers, with children themselves never included as participants in research projects (Scott, 2000). This scenario changed with the advent of what is often referred to as the 'new' sociology of childhood in the 1980s. This new paradigm of childhood research in sociology (Prout and James 1997) changed the focus from looking at childhood as a period of life to approaching it as permanent structural segment of society (Qvortrup, 2007) whose membership continually changes as new children enter into it and older children move out of it. Conceiving of childhood as a structural feature - rather than as a biological given - helps us appreciate how and why experiences of childhood differ across time and place. This movement within sociology which sought to give children "conceptual autonomy" (Thorne, 1987) and carve a space for a sociological understanding of children's childhoods has grown rapidly since then with the establishment of several dedicated university programmes, journals, book series and professional associations (Bühler-Niederberger, 2010). Such sociological insights into children's lived experiences and embodied knowledge are indispensable for arriving at a better understanding of society itself as Mayall (2013, pp. 2) puts it:

There are advantages to all generations and societies if we acquire greater understanding of and respect for children and for childhood (just as feminism has altered understandings of women). Children, after all, constitute about onethird of humanity, and, across the world, contribute to the economic welfare of families and societies.

As in the extract above, childhood scholars draw a distinction between children as human beings/social actors and childhood as a mutable set of cultural ideas/structural segment of society (Cunningham, 2005). Of course, how adults see children - i.e. dominant cultural ideas about childhood - directly impact upon the ways in which children are treated in a given society particularly with respect to legal rights, policy and professional practice (Neale, 2004). The intellectual remit of the sociology of childhood is to better understand children's childhood - i.e. their own lived experiences - as well as to account for the ways in which dominant cultural ideas of childhood are being framed and thereby identify their implications for children. In what follows, I outline what sociology of childhood - and childhood studies more broadly - has to offer to leisure sociology.

Leisure sociology despite its intellectual growth has remained somewhat isolated and estranged from mainstream sociology (Stebbins, 2018; Samdahl and Kelly, 1999). Similarly, the sociology of childhood has not managed to dislodge unidirectional models of socialization - that see children as passive receptacles of social instruction - from mainstream sociology with textbooks and survey sources still largely ignoring children's lives or for that matter the scholarship emerging from childhood studies (Bühler-Niederberger, 2010). Leisure scholars have long realized the need to build bridges with other communities of scholars to lend greater visibility to leisure scholarship and make an impact beyond the field of leisure studies (Parr and Schmalz, 2019; Fletcher et al., 2017; Shaw, 2000; Deem, 1999). Therefore, insofar as children's leisure is concerned, the lack of sustained engagement between leisure sociologists and childhood sociologists till date can be turned into an opportunity for mutual benefit. However, including children's voices in leisure theory or critiquing the adult-centrism 
of contemporary leisure research is not a straightforward exercise. The history of feminist leisure research offers some useful lessons here for a child-centred leisure research. Following criticism from feminist scholars who highlighted the absence of women's leisure from contemporary leisure theories, empirical studies in the 1980s began to acknowledge the need to study women's leisure and, in the process, largely followed a 'add woman [to existing leisure theories] and stir' model before more nuanced feminist analysis of gender and power developed in leisure studies (Henderson, 2013, 1994). My intention therefore is not to produce an add-childrenand-stir model of leisure studies that maintains status quo and merely pays lip service to children's concerns and rights. To effectively address these concerns, leisure sociology needs to invest in - what leisure scholar Fox (2000) terms - a disruptive collaboration with the 'new' sociology of childhood. Disruptive collaboration here signifies an approach whereby critiques and political action from points of view beyond leisure studies are incorporated into it, in the processes unsettling taken for granted assumptions and contributing to the development of a more diverse community of leisure scholars. In a sense, the current body of child-centred leisure research within leisure studies - as outlined previously - mostly follow an add-children-and-stir model, which a process of disruptive collaborations with childhood studies can help tranform. Such a disruptive collaboration and the resultant diversification of leisure research will be a major step forward for the sub-disciplinary sociology of leisure which is currently "largely invisible in modern Western sociology" (Stebbins, 2018, pp. 51). This collaboration equally demonstrates, what Ní Laoire describes as, "the disruptive impact that childhood studies can have in terms of challenging the adultcentrism of so many fields of research" (qtd. In Alanen et al., 2018, pp. 133).

Like any other area of research, there are divergences within childhood studies in terms of theoretical and methodological tools used. Indeed, such debates have propelled this scholarly community forward. It would therefore be counterproductive to try and outline a definite set of ideas and theories developed by childhood sociologists that can be useful to leisure scholars working with children. Instead, I have isolated what I consider to be the most relevant debates in childhood research that leisure sociologists studying children's leisure can draw upon and contribute to. In doing so, I acknowledge the personal biases and exclusions that such a selection invariably entails. I will now sketch the key debates around children's agency, generational order, and participation that are particularly relevant to a sociological exploration of children's everyday leisure.

\subsection{Key Debates in Childhood Studies: Child's Agency, Generational Order and Lived Citizenship}

The conceptual shift from characterizing children as apprentice adults and 'welfare dependents' - who are relatively incapable and require care and protection - to seeing them as social actors and 'young citizens' (Neale, 2004) - who are entitled to respect, rights and participation - has been accomplished within the sociology of childhood by highlighting children's agency and their contribution to the social environment they inhabit (Mayall, 2002; Morrow, 1996). Recognition of children's agency has over the past few decades assumed a largely taken-for-granted status within the sociology of childhood and it is ubiquitous in the literature that has emerged within this area. In 
understanding children's agency, childhood scholars have advanced competing models. One set of scholars understand children as "independent social actors" (James and James, 2012, pp. 3) and regard agency as an inherent quality or as a context-bound competency of children (Mayall, 2002; James, Jenks and Prout, 1998). In contrast, those enlisting post-humanist approaches have located children's agency in relations of interdependence - something that applies as much to adults as to children - thus dispersing agency across the human and the non-human (Eßer, 2017; Oswell, 2013; Prout, 2011). In the latter approach, children's agency is understood in relational terms, as dependent and ontologically heterogeneous (Lee, 2001). Notwithstanding the various theoretical models used, this persistent interest in children's agency has a primarily political role within childhood studies which is to rebalance power differentials and find means of studying children that does not reproduce those power differences and prejudices (Oswell, 2013). As Mayall (2013, pp. 2) puts it: "the sociological study of childhood is a political enterprise, aimed at improving respect for children's rights in society, including their rights to distributive justice". Although "children's agency has been central and essential to social studies of childhood" (Mason and Bessell, 2017, pp. 257), leisure sociologists working with children (Fowlie, Eime, and Griffiths, 2020; Fader, Legg and Ross, 2019; Fletcher, 2019; Asakitikpi, Adeyemi and Nnamani, 2018; Rhoden, Hunter-Jones and Miller, 2016; Shannon, 2016; Mjaavatn, 2016; Jeanes and Magee, 2012; Haglund and Anderson, 2009; Shannon and Shaw, 2008; Macdonald et al., 2005; Yuen, Pedlar and Mannell, 2005; Zabriskie and McCormick, 2003) have thus far largely eschewed debates about children's agency, and in the process missed a potential opportunity of impacting childhood studies. Leisure as a social space and institution, can offer an important point of entry to probe and theorize children's agency - thereby enriching our understanding of how children experience leisure and shape leisure spaces in interaction with others whilst also contributing to one of the key debates within childhood studies.

Linked to notions of agency, are the conceptual frameworks of generational order and children's lived citizenship which can offer added value to a critical sociology of children's leisure. Childhood studies recognizes children's agency and contribution to society whilst also paying attention to their structural positioning in relation to adults (Leonard, 2016). Age and generation here emerge as key units for analysing children's social locations wherein "age is an embodied form of difference that is both materially and discursively produced and embedded in relations of power and authority" (Thorne, 2007 , pp. 150). Generation is thus a conceptual tool for understanding age relations in a given context, where those occupying the category of adult undertake their positional performance in contradistinction to those occupying the category of child (Alanen, 2014). The social locations of childhood and adulthood are internally related, but they constitute a relation of inequality. This brings into sharp focus the idea that children's "lives, experiences, and knowledges are not only gendered, classed, and 'raced' (and so on) but also ... generationed" (Alanen, 2014, pp. 145). Childhood is a profoundly unequal space where generational inequality between children and adults - in terms of power, social privileges and subordination - play out in concert with race, ethnicity, class, gender and ability to construct multiple lived realities of childhoods within any given time-space (Wells, 2017). Recognizing these power inequalities does not diminish children's agency but gives us a sense of the social context in which agency is situated. In fact, those adopting a relational perspective argue that children's agency is 
always embedded within their inter- and intra-generational positionings and relationships (Leonard, 2016). These debates are extremely cricual for studying children's leisure as a situated and embodied experience, but barring a few notable exceptions (for example Fletcher, 2019; Irving and Giles, 2011; Shaw, 2008) leisure scholars are yet to grapple fully with the ways in which childhood and adulthood (parenthood) are coconstituted.

Children are, in one sense, not full citizens and hence do not enjoy privileges such as voting rights and do not carry obligations like financial responsibilities like adults do (Cockburn, 2013). This individual-centric deficit model of citizenship has been critiqued by childhood scholars who advocate a move towards a conception of citizenship based on principles of redistribution that emphasizes the interconnected nature of human experiences (Baraldi and Cockburn, 2018). Enlisting this inclusive vision of citizenship, childhood scholars posit the idea of children's lived citizenship that focuses on citizenship as practiced and experienced (Warming, 2019; Moosa-Mitha, 2005). Key to this process-driven idea of citizenship is children's participation which assumes multiple forms. The most obvious site for children's political participation is institutional settings such as student council in schools (Wyness, 2018) but it also extends to spaces that children inhabit or co-create with others such as those within sports teams (Cockburn, 2017). To fully understand children's role as active participants it is important not only to probe the physical spaces that adults deem suitable for children but to also pay attention to the social, cultural and discursive spaces that children cocreate; spaces that carry "possibilities for children and adults to contest understandings, values, practices and knowledges" (Moss and Petrie, 2002, pp. 10). Whilst discussions on children's participation, rights and lived citizenship have looked into sports and leisure spaces of children (see Cockburn, 2017), they are being spearheaded by childhood scholars with no substantial contribution from leisure scholars yet. This is yet another domain of childhood studies where leisure scholars can make important contributions.

\subsection{Genres of Children's Leisure: A Conceptual Map}

Thus far in this article I have demonstrated the need for a disruptive collaboration (Fox, 2000) between leisure studies and childhood studies if we are to fully appreciate children's leisure experiences and meaning making as well as identify the role of leisure within the unequal landscape of lived childhoods. Such an endeavour, as I have shown above, requires leisure scholars researching children's leisure to engage directly with some of the key debates around children's social actorship and their structural positioning that are missing from existing leisure studies' accounts of children's leisure. As a way of illustrating what a critical sociology of children's leisure - that cross-cuts and interlaces both leisure studies and childhood studies - might look like, here I will outline a conceptual map for unpacking the sociology of children's leisure in the global north (or the minority world). In presenting this map of what I call three genres of children's leisure, I am not suggesting a "one leisure size fits all” approach (Henderson, 1996, pp. 139) for studying children's leisure. Leisure typologies are not the same for all children within the global north itself, but what I aim to offer through this exercise is an illustration of how to work with concepts from both leisure theory and childhood sociology in a way that is child-centred and that offers avenues for theorizing children's 
leisure in a holistic and critical manner. The empirical insights that can garnered through the use of this map has the potential to contribute simultaneously to childhood studies and leisure studies. This tripartite model can be modified, critiqued, and remade by future leisure scholars doing empirical work on children's leisure.

The broad remit of leisure as a conceptual category and the lack of consensus over its definition create particular challenges for any researchers studying leisure empirically. As Cunningham (1980, pp. 13) rightly points out, people "talk about concrete, discrete activities" which vary across time and place and not about leisure per se. Therefore, in conducting empirical studies about people's everyday leisure, leisure researchers deploy varying typologies or categories of leisure to demarcate the object of their study from within the larger domain of leisure and by doing so they help refine exiting theorisations of leisure. However, some of the prevalent typologies cannot accommodate the particularities of children's leisure. For instance, Stebbins' (2007, pp. 5) notion of serious leisure is quite popular within leisure studies and he defines it thus: "Systematic pursuit of an activity that people find so substantial, interesting or rewarding that they typically launch themselves on a (leisure) career centred on acquiring and expressing a combination of its special skills, knowledge and experience". The assumptions made here are adult centric and does not necessarily apply to children's leisure choices which - as previous studies (Friedman, 2013; Lareau, 2011; Vincent and Ball, 2007; Shannon, 2006) show- are often contingent upon parental decisions and do not rest solely with children wanting to "launch themselves on a (leisure) career" (Stebbins, 2007, pp. 5). The implied person in Stebbins' (2007) theory is never imagined as a child - which in itself raises important questions about the wider non-recognition of children's personhood and subjectivity within social sciences (Wells, 2017).

Psychologists studying children's leisure have often deployed a binary of active leisure (eg. sports and physical exercises) and passive leisure (eg. reading and watching TV) to map out children's everyday leisure pursuits (Holder, Coleman and Sehn, 2009; Csikszentmihalyi and Hunter, 2003). Others have used three-tier typologies for researching children's leisure: achievement-oriented/active leisure (eg. sports), social leisure (eg. peer activities), and passive/time-out leisure (eg. watching TV) (Shin and You, 2013; Passmore, 2003). Meanwhile, childhood and family sociologists studying children's leisure have usually attended to one kind of leisure activity - for example extracurricular activities (see Friedman, 2013; Lareau, 2011; Vincent and Ball, 2007) - in isolation without situating them within the wider leisure repertoire of children's everyday lives. In pulling together the various strands of existing empirical scholarship on children's leisure - most of which has actually been undertaken outside leisure studies - it is apparent that we need a holistic approach that does not isolate different aspects of children's leisure geographies but treats them as interlocking constituents of children's wider everyday leisure repertoire. Looking at all the interlocking components of children's everyday leisure will enable us to draw out the dynamic links between children's leisure activities, their agency, and their social locations. Existing typologies of active/ passive/social leisure cannot grasp the meanings that parents and children construct around different sets of leisure actions and they also do not reveal the power relations and social positionings through which leisure experiences are produced. Therefore, I propose a conceptual framework which synthesizes the existing strands of research and formulates them into three interrelated genres of children's leisure namely 'structured/ organized leisure', 'family leisure', and 'casual leisure'. Activities contained within each 
genre of leisure are context-dependent and share family resemblances. I will now describe each of the three genres of children's leisure in turns.

\subsection{Structured Leisure}

Structured or organized leisure encompasses those paid-for leisure classes that children partake in and which are spatially and temporally demarcated in children's weekly schedules. Often dubbed as 'extra-curricular' or 'out-of-school/after-school' activities, this genre of leisure has attracted immense scholarly attention in the last two decades, albeit largely among family, childhood and education scholars. Studies in the US and the UK have repeatedly found that school-age children are spending a significant portion of the week in structured leisure activities and in this regard clear differences in the number and frequency of such leisure participation have been found between children of working class and middle-class parents (Putnam, 2015; Bennett, Lutz and Jayaram, 2012; Lareau, 2011; Lareau and Weininger, 2008). This signifies a dominant trend among middle-class parents who treat these organized leisure lessons as crucial sites for their children to imbibe key behavioural competences and skills, become familiar with competitions (for example, in sports) and add extracurricular achievements to their CV - all of which help them navigate educational and career success in the future (Reay, 2017; Friedman, 2013; Lareau, 2011; Nelson, 2010; Pugh, 2009; Devine, 2004; Dunn, Kinney and Hofferth, 2003). This genre of children's leisure activity therefore plays an important role in maintaining and furthering social inequalities since children from all social classes do not enjoy similar level of access to these paid-for lessons. For instance, Lareau's $(2011,2002)$ study in the US found that parents' motivation to send children to multiple leisure lessons is nested within a classed ideology of child-rearing wherein middle-class parents see their children as projects to be developed and therefore devise a strategy of concerted cultivation aimed at nurturing children's skills and talents through organized activities. In a similar vein, Vincent and Ball's (2007) research with middle-class parents in London revealed that structured leisure pursuits constitute middle-class parents' response to the urgency they feel in developing key skills in their children and therefore these activities are crucial in the 'making up' of middle-class childhoods. Moreover, Reay's (2010) study with primary school children in London found that middle-class parents were spending more than $£ 100$ a week for their children to take part in outside-of-school learning opportunities and cultural activities such as drama and music. That amount of money was more than what some working-class lone mothers on benefits, in the same study, had per week to live on (Reay, 2010). Reay (2010) goes on to argue that being able to afford culturally enriching and educational leisure activities for their children is part of the social class reproduction mechanism within families and it thus informs the educational advantages that middle-class children enjoy. Relatedly, Shannon (2006) argues that parental influences on children is not limited to specific leisure activities or interests but also extends to leisure values and attitudes. In other words, parents' leisure-related messages to their children revolve around the valuation of leisure and its role in life; often sculpting hierarchies of leisure where structured extracurricular activities are perceived as more beneficial than unstructured ones (Shannon, 2006).

A sociological approach to children's structured leisure activities goes beyond the understanding of individual experiences and examines the wider social processes that 
feed into this growing trend as well as identifies its consequences. We know that the increasingly popularity of children's after-school lessons - which are adult-directed and supervised - has been matched by the decline in children's unsupervised and outdoor play as risk anxieties about children's safety have assumed greater traction (Gill 2007; Holloway and Pimlott-Wilson, 2014). This has been further accentuated by changing ideals of child-rearing as good parenting is increasingly being constructed as "childcentred, ... emotionally absorbing, labor intensive, and financially expensive" (Hays 1996, pp. 8). Facilitating children's organized activities have become integral to this middle-class notion of intensive parenting. Although scholars have also identified parents' work schedules, single-versus-two-parent households, resident-versus-nonresident parenting and geographical location as external factors that further shape parents' ability to facilitate children's organized leisure activities (see for example Fletcher, 2019; Jenkins, 2009; Swinton, Freeman and, Zabriskie, 2009), I concur with Lareau and Weininger (2008) that middle-class parents still have more leeway and resources to negotiate these constraints than their working-class counterparts.

The implications of this genre of children's leisure are many. Firstly, children's participation in organized leisure lessons contributes heavily towards the institutionalization of childhood (Zeiher, 2011; Edwards, 2005) which compartmentalizes children's everyday geographies across an array of adult-supervised, and largely chronological-age based social institutions. Secondly, through their disproportiate access to paid-for leisure lessons middle-class children pick up key skills and corner social advantages that working-class children lose out on - hence reproducing class advanatages (Reay, 2017; Lareau, 2011). Thirdly, these activities have a direct bearing on parents' daily schedules and their own leisure opprtunities (Irving and Giles, 2011; Such, 2009). For instance, growing organized leisure schedules have quickened the rhythm and pace of family life within middle-class families with parents having to spend significant amount of time, money and energy in acconmpanying their children to and from these activities (Berhau, Lareau and Press, 2011; Darrah, Freeman and English-Lueck, 2007). Such leisure activity management labour is gendered, and they construct parents as parents of a particular kind. In the US, for instance, middle-class women who devote their time and energy in facilitating their children's sports participation are often seen in popular culture as soccer moms and it is through their children's leisure activity management that they get positioned as 'good mothers' (Swanson, 2009). Relatedly, structured leisure activities especially sports often serve as a dominant cultural context for contemporary fathering and links have been drawn between sports fathering and questions of masculinity (Fletcher, 2019; Edwards, 2019; Jeanes and Magee, 2011; Kay, 2007). However in current understandings of 'leisurebased fatherhood' (Such, 2009), leisure scholars are only beginning to engage with how race and ethnicty is pivotal is to these processes (Edwards, 2019; Fletcher, 2019).

From the above cited literature it is abundantly clear that structured leisure as a genre is reshaping contemporary childhoods and parenthoods in the global north. Indeed, echoes of this trends can be found among middle-class families in urban India and China (Sen 2014; Naftali 2010). However, barring a few notable exceptions (Fowlie, Eime and Griffiths, 2020; Fader, Legg and Ross, 2019; Cockburn, 2017; Fletcher et al., 2017; Sen 2014; Friedman, 2013; Shannon, 2006; Dunn, Kinney and Hofferth, 2003), studies on children's organized leisure have largely documented parental accounts (Lareau, 2011; Reay, 2017, 2010; Pugh, 2009; Such, 2009; Jenkins, 2009; Vincent and Ball, 2007; Devine, 2004) or that 
of adult instructors and facilitators (Jeanes et al., 2019; Jeanes, O’Connor and Alfrey, 2015) and we still know relatively little about how children negotiate their agency and lived citizenship in leisure spaces. Moreover, extant understandings of the link between social class and children's organized leisure are based on the experiences of white middle-class parents with the voices of black and ethnic minority parents laregly under-represented in this literature. Therefore, leisure sociologists need to take stock of this important area of research - which till date has been driven by family, education and childhood scholars - and contribute to these debates; in the process enriching leisure theories and taking leisure concepts to other research communities. There is mutual benefit here for both childhood and leisure studies if leisure scholars who have already started on the journey to amplify children's voices pay attention to questions of children's agency, participation and generational power relations - and use those insights to lend greater visibility to children in mainstream leisure theory.

\subsection{Family Leisure}

Family leisure refers to "activities that different family members participate in together" (Shaw, 1997, pp. 99). In contemporary times, vernacular expressions such as 'family time' or 'spending time with family' which signal family leisure activities have become ever more prominent (Kremer-Sadlik, Fatigante and Fasulo, 2008). However, the historian Gillis (2003) has shown that the very notion of 'family time', centred around children, emerged in Europe and North America only in the nineteenth century and was initially confined to the households of Victorian elites. The discourse of 'family time' has spread more widely since then in lockstep with the changing social construction of childhood. With children's lives quarantined from the adult world, children have historically been pulled out of paid work and put into compulsory schooling, making them economically 'worthless' but emotionally 'priceless' (Zelizer, 1994). This in turn has reconfigured the intergenerational power dynamics within families, as children have come to acquire central importance within family practices, and they have been recognized as legitimate stakeholders within the institution of the family (Chambers, 2012; Gillis, 2003).

As a collective activity, family leisure involves children alongside siblings, parents, and other members of the family. Sociologists have increasingly acknowledged that children make manifold contributions to the functioning of the household (Smart, Neale and Wade, 2001; Morrow, 1996). Understanding the way shared leisure activities are experienced by members of the family including children can therefore offer new avenues into analysing the social institution of the family itself (Shaw, 2008). After an initial lull, family leisure is one area of research where leisure scholars have taken the lead in exploring the subjective experiences and outcomes of family leisure in different social settings (Trussell, Jeanes and Such, 2017; Shaw, 2008). Nevertheless, when it comes to families with children, our historical understanding derives primarily from parental accounts as children were usually seen but not listened to in family leisure research (Jeanes, 2010). More recently, however, empirical studies have begun to explore children's perspectives on family leisure and where these activities fit in the larger scope of children's everyday geographies.

Child-focused family leisure research have found that children undertake these shared family leisure activities for their intrinsic 'fun' qualities (Macdonald et al., 2005), but parents participate in it not for its own sake but as a means for their children to imbibe family values and other traditions as well as to cement family bonds and 
patterns of family communication (Shaw, 2008; Shaw, Havitz and Delemere, 2008; Shannon, 2006; Shaw and Dawson, 2001). As parents assume the role of 'leisure educators' (Robertson, 1999), family leisure becomes a means for reinforcing intergenerational family dispositions (Quarmby and Dagkas, 2010). Studies conducted with families in cities have demonstrated that middle-class families have reconfigured urban consumption infrastructure by moving together and consuming city spaces through family outings, which have also served to construct family spaces outside the home (Karsten, Kamphuis and Remeijnse, 2015; Karsten and Felder, 2015; DeVault, 2000). These studies recognize the significance of family leisure for studying families and have in the recent past attempted to locate and listen to children within family leisure. But conversely, empirical studies that locate family leisure within children's wider everyday leisure repertoire - that is family leisure as part of children's leisure geography - is largely absent. Such a study would involve charting the manner in which family leisure activities transpire in relation to school patterns, structured leisure schedules and other everyday leisure activities of children. The tripartite framework for studying children's leiusre presented in this article can therefore offer such a tool for locating children's family leisure experiences within the spectrum of children's wider leisure lives.

The conceptual manoeuvres suggested above are significant to the development of a critical sociology of children's leisure for two broad reasons. Firtsly, greater theoretical integration of family leisure into a holistic framework of children's everyday leisure is long overdue and will make a significant contribution in itself. Secondly, family leisure is a focal point where leisure studies, family studies and childhood studies meet. Consequently, it creates avenues for leisure researchers to establish links with those allied field and make their rich body of work on family leisure more accessible to scholars of childhood and family life.

\subsection{Casual Leisure}

The term 'casual leisure' is derived from Stebbins (1997, pp. 18) who defines it as "immediately, intrinsically rewarding, relatively short-lived pleasurable activity requiring little or no special training to enjoy it". Although such a description can be applied to certain forms of family leisure activities as well, here it is directed at those unstructured, ludic, and solitary leisure activities which do not correspond to either organized activities or collective family leisure experiences but are nonetheless extremely important components of children's everyday leisure. Children's interaction with media technologies, playing with friends and toys, and various nonconsumptive activities such as reading, storytelling, and other imaginative avenues of solitary leisure can be seen through the prism of 'casual leisure' (Stebbins, 1997, 2007). The existing literature takes a fragmentary approach to children's casual leisure, looking into discrete aspects of it such as digital leisure and playing, with little mention of solitary leisure. Pulling them together under the rubric of casual leisure offers opportunities for in-depth study and theory building both of which are indispensable to the proposed sociology of children's leisure.

With the expansion of 'new' media, especially of information and communication technologies (ICTs), sociological interest has grown substantially around how children interact with the internet and digital media (Livingstone, Mascheroni and Staksrud, 2018; Livingstone et al., 2014; Livingstone, 2009, 2007; Holloway and Valentine, 2003). In a pioneering study of children's ICT use in their everyday contexts of the school and the 
home, Holloway and Valentine (2003) challenged the technological determinism that assumes that access to technologies will invariably produce fixed outcomes for children. Instead their empirical study revealed that children as competent social actors were using ICT to forge and enhance social relationships and children were also identifying potential risks of online activities and coming up with ways to avoid them. Children, they argued, were more concerned with the influence of ICT on their lived identities at home and school and how these were perceived by their peers than they were about future job prospects that technological literacy can bring. These arguments have continued to frame the discussion around digital media within childhood studies (see Livingstone, 2009). It has been repeatedly pointed out that notwithstanding how children employ ICT in their local context, children are largely constructed within the dominant adult-centric discourses as lacking an adequate sense of responsibility or emotional competence to match their growing technological abilities (Wyness, 2012; Holloway and Valentine, 2003). There is also a growing body of literature on how parents mediate children's digital leisure practices by laying down rules or by co-using ICT devices with them (Martins, Matthews, and Ratan, 2017; Symons et al., 2017; Sonck, Nikken, and De Haan, 2013; Shin and Huh, 2011; Livingstone and Helsper, 2008). However, in-depth understanding of how children navigate these parental mediations and exercise agency in these contexts is rather thin on the ground. And leisure scholars are yet to make meaningful contributions to this important area of sociological and policy interest especially since children's internet use has attracted immense media attention in recent years.

Besides children's use of media technologies as forms of casual leisure, tactile and outdoor play with peers and family members are also integral to their everyday casual leisure geographies. Psychological paradigms have been dominant in the framing children's play around question of children's development, but such a progressoriented rhetoric is often adult-imposed and fail to capture the way play as a social action matters to children (Sutton-Smith, 1997). Social research with children points to their interactive cultures of play where rules of established games circulate among children as well as between children and adults, as children interpret social norms in creative ways and invent or improvise new games from existing ones (Corsaro, 2012; Lancy, 1996; Opie and Opie, 1969). More recent empirical works (Burn and Richards, 2014; Willett et al., 2013) are beginning to unpack how these tactile games are coexiting with digital leisure, but evidence till date strongly suggest that digital leisure has not wiped away tactile games and lores of children but have refashioned their role within children's casual leisure geographies. Furthermore, studies (Farquharson et al., 2019, Renold, 2002; Connolly, 1998) have over the years documental institutional racism, sexism, ableism and queerphobia within children's play spaces - particularly school playgrounds - and therefore there is an opportunity here for leisure researchers to challenge these exclusionary practices and contribute to policy conversations around inclusivity in children's play spaces (for examples, see Jeanes and Magee, 2012).

The above discussion on children's digital leisure and play shows that children's casual leisure geography is complex and context dependent. They pointed to the need for engaging with children as well as their parents and peers to understand how these leisure practices unfold within the patterns of everyday life and how parental mediation and children's agency are negotiated. Unfortumately, leisure scholars working on children's digital leisure continue to deploy technological-determinism in their approach and enlist uni-directional models of socialization that produce children as passive non-actors (see Asakitikpi, 
Adeyemi and Nnamani, 2018). Leisure scholars studying children's digital leisure should instead pay greater attention to the conceptual developments around children's media use emerging from childhood studies and move beyond the technological-determinism and socialization paradigm that are so ingrained in the former.

To sum up, the conceptual map of studying children's leisure as an interlocking structure of three different genres of leisure - structured, family, and casual leisure - is a useful and robust framework for engaging with and understanding children's everyday leisure experiences as well as the social context in which they are embedded. It lends itself to a critical sociology of children's leisure that draws upon concepts and theoretical debates across leisure sociology and the 'new' sociology of childhood. Such a critical sociology of children's leisure that builds upon and contributes simultaneouly to leisure studies and childhood studies is not intended to further fragment an already vulnerable leisure studies. On the contrary, leisure scholars should address the research gaps I have outlined above and take up the opportunities I have sketched in this article in order to: (a) build bridges with allied fields like childhood studies and thereby enrich their own work, (b) create impact of their work outside the silos of leisure research, (c) revitalize and expand mainstream leisure theory by going beyond its adult-centrism, and (d) improve possibilities of research funding by co-creating projects with colleagues in chidlhood studies. A critical sociology of children's leisure - along the lines of the map presented above - can chart new territories for the future of a vibrant leisure studies and those of us involved in the field must not leave these opportunities untapped.

\section{Conclusion}

In this article I have taken to task the prevailing adult-centrism of leisure theory which has thus far been so naturalized and taken-for-granted that researchers (barring a few exceptions) have failed to robustly challenge it. By making a case for a critical sociology of children's leisure - that is built upon a sustained dialogue between leisure sociology and childhood sociology - I have broken new grounds which future scholars can take forward. In doing so, I have also drawn attention to the challenges such a critical child-centred approach faces within the sociology of leisure which has an adultbias built into it. Even if the sociology of leisure itself is an estranged child of mainstream sociology (Stebbins, 2018), real children and their lived childhoods have always been estranged and marginal to theory building within leisure sociology.

Drawing upon Fox's (2000) idea of disruptive collaboration I have argued that using concepts and theoretical frameworks from childhood studies can enrich the work of leisure sociologists working on children's leisure. Such endeavours will not only widen the breadth of leisure theory and make it more inclusive, but also enable leisure scholars to have an impact beyond the silos of leisure research and reach out to fields like childhood and family studies. As a way of illustrating what such a disruptive collaboration between leisure studies and childhood studies might entail, I have briefly sketched out the intellectual contours of the 'new' sociology of childhood - and the interdisciplinary realm of childhood studies - and unpacked some of the key concepts that might be useful to leisure scholars researching children's leisure. In producing a roadmap for future empirical works on children's leisure, I have synthesized existing literature from both these fields of research to construct a conceptual framework of three genres of children's leisure, namely organized/structured, 
family, and casual leisure. This child-centred framework largely applies to children in the global north/minority world - and future scholars using it can modify, critique, or develop it further. I have argued that researchers should not treat one aspect of children's everyday leisure - such as digital leisure or organized leisure lessons - in isolation but as interlocking components which bleed into each other. Through a critical sociology of children's leisure, leisure studies can reassert its commitment to social justice and equality that takes into account children's needs, social contributions and rights.

Notwithstanding the fact that interdisciplinarity has always been the watchword for leisure scholarship, I posit that leisure studies should also see itself as a "magpie subject" that is to say an academic subject which at its "base contains others' pearls of wisdom" while also nurturing "insights, theories and empirical research of its own" (Blakemore and Griggs 2007, pp. 3). Without such regular contact and dialogue with other fields of research, leisure studies will become further intellectually isolated (Samdahl and Kelly, 1999). While the issue of intellectual insularity persists, the institutional status and vitality of leisure studies has been further threatened in recent years by the increasing neoliberalisation of higher education and the splintering of leisure studies curricula into various subfields that do not feed back to their intellectual roots (Parr and Schmalz, 2019; Fletcher et al., 2017; Elkington, 2013). As leisure studies "continues to struggle ... to claim a seat at the proverbial academic and research tables" (Parr and Schmalz, 2019, pp. 376), introspection about its foundational assumptions - in this case adult centrism- and reaching out to potential allies like childhood studies can translate into a fresh direction of growth and vitality for leisure scholarship. Therefore, the novelty of the call for a disruptive collaboration between leisure studies and childhood studies issued in this article holds great promise for the future of leisure studies.

Availability of Data and Material N/A

Code Availability N/A

Funding N/A

\section{Compliance with Ethical Standards}

Conflicts of Interest/Competing Interests None.

Open Access This article is licensed under a Creative Commons Attribution 4.0 International License, which permits use, sharing, adaptation, distribution and reproduction in any medium or format, as long as you give appropriate credit to the original author(s) and the source, provide a link to the Creative Commons licence, and indicate if changes were made. The images or other third party material in this article are included in the article's Creative Commons licence, unless indicated otherwise in a credit line to the material. If material is not included in the article's Creative Commons licence and your intended use is not permitted by statutory regulation or exceeds the permitted use, you will need to obtain permission directly from the copyright holder. To view a copy of this licence, visit http://creativecommons.org/licenses/by/4.0/.

\section{References}

Alanen, L. (1988). Rethinking childhood. Acta Sociologica, 31(1), 53-67. 
Alanen, L. (1992). Modern childhood? Exploring the 'child question' in sociology. Jyväskylä: Kasvatustieteiden Tutkimuslaitos.

Alanen, L. (2014). Childhood and Intergenerationality: Toward an intergenerational perspective on child Wellbeing. In A. Ben-Arieh, F. Casas, I. Frønes, \& J. Korbin (Eds.), Handbook of child well-being (pp. 131160). Dordrecht: Springer.

Alanen, L., Baraldi, C., de Coninck-Smith, N., Ní Laoire, C., \& Tisdall, K. (2018). Cross-disciplinary conversation in childhood studies: Views, hopes, experiences, reflections. Childhood, 25(2), 127-141.

Allison, M. T. (2000). Leisure, diversity and social justice. Journal of Leisure Research, 32(1), 2-6.

Ambert, A.-M. (1986). Sociology of sociology: The place of children in north American sociology. Sociological Studies of Child Development, 1(1), 11-31.

Ariès, P. (1962). Centuries of childhood. Harmondsworth: Penguin.

Asakitikpi, A. O., Adeyemi, J., \& Nnamani, J. A. (2018). Socialization through leisure: A case study of nickelodeon cable television. International Journal of the Sociology of Leisure, 1(1), 99-115.

Baraldi, C., \& Cockburn, T. (2018). Introduction: Lived citizenship, rights and participation in contemporary. In C. Baraldi \& T. Cockburn (Eds.), Theorising childhood (pp. 1-27). Cham: Palgrave Macmillan.

Bennett, A. (2013). Youth culture, leisure and lifestyle. In T. Blackshaw (Ed.), The Routledge handbook of leisure studies (pp. 572-583). London: Routledge.

Bennett, P. R., Lutz, A. C., \& Jayaram, L. (2012). Beyond the schoolyard: The role of parenting logics, financial resources, and social institutions in the social class gap in structured activity participation. Sociology of Education, 85(2), 131-157.

Berhau, P., Lareau, A., \& Press, J. E. (2011). Where families and children's activities meet: Gender, meshing work, and family myths. In A. I. Garey \& K. V. Hansen (Eds.), At the heart of work and family: Engaging the ideas of Arlie Hochschild (pp. 43-60). New Brunswick: Rutgers University Press.

Blackshaw, T. (Ed.). (2013). The Routledge handbook of leisure studies. London: Routledge.

Blakemore, K. \& Griggs, E. (2007). Social policy: An introduction (3rd ed.). Maidenhead: Open University Press.

Blatterer, H. (2007). Contemporary adulthood: Reconceptualizing an uncontested category. Current Sociology, 55(6), 771-792.

Boulila, S. (2019). Straight(ening) salsa? The heterosexual matrix, romance and disciplinary spaces. Leisure Studies. https://doi.org/10.1080/02614367.2019.1703139.

Brittain, I., Biscaia, R., \& Gérard, S. (2020). Ableism as a regulator of social practice and disabled peoples' self-determination to participate in sport and physical activity. Leisure Studies, 39(2), 209-224.

Bühler-Niederberger, D. (2010). Introduction: Childhood sociology — Defining the state of the art and ensuring reflection. Current Sociology, 58(2), 155-164.

Burn, A. N., \& Richards, C. O. (Eds.). (2014). Children's games in the new media age: Childlore, media and the playground. Burlington: Ashgate.

Chambers, D. (2012). A sociology of family life: Change and diversity in intimate relations. Cambridge: Polity Press.

Coalter, F. (1989). Freedom and constraint: The paradoxes of leisure. London: Routledge.

Cockburn, T. (2013). Rethinking children's citizenship. Basingstoke: Palgrave MacMillan.

Cockburn, T. (2017). Children and the 'social cohesion' agenda in sport: Children's participation in 'ethnically mixed' sports teams in the north of England. Children \& Society, 31(1), 50-60.

Connolly, P. (1998). Racism, gender identities and young children: Social relations in a multi-ethnic, innercity primary school. London: Routledge.

Corsaro, W. A. (2012). Interpretive reproduction in children's play. American Journal of Play, 4(4), $488-504$.

Csikszentmihalyi, M., \& Hunter, J. (2003). Happiness in everyday life: The uses of experience sampling. Journal of Happiness Studies, 4(2), 185-199.

Cunningham, H. (1980). Leisure in the industrial revolution, c.1780-c.1880. London: Croom Helm.

Cunningham, H. (2005). Children and childhood in Western society since 1500. Harlow: Pearson Longman.

Darrah, C. N., Freeman, J. M., \& English-Lueck, J. A. (2007). Busier than ever! Why American families can't slow down. Stanford: Stanford University Press.

Deem, R. (1999). How to get out of the ghetto? Strategies for research on gender and leisure for the twentyfirst century. Leisure Studies, 18(3), 161-177.

DeVault, M. L. (2000). Producing family time: Practices of leisure activity beyond the home. Qualitative Sociology, 23(4), 485-503.

Devine, F. (2004). Class practices: How parents help their children get good jobs. Cambridge: Cambridge University Press.

Dunn, J. S., Kinney, D. A., \& Hofferth, S. L. (2003). Parental ideologies and children's after-school activities. American Behavioral Scientist, 46(10), 1359-1386. 
Edwards, R. (2005). Introduction: Conceptualising relationships between home and school in children's lives. In R. Edwards (Ed.), Children, home and school: Regulation, autonomy or connection? (pp. 1-23). London: RoutledgeFalmer.

Edwards, R. (2019). Towards an understanding of fathers' involvement in children's sporting activities as racial fathering practices. Leisure Studies, 38(6), 875-881.

Elias, N. (1978). The civilizing process: The history of manners. Oxford: Blackwell.

Elkington, S. (2013). Ways of seeing degrees of leisure: From practice to pedagogy. Leisure Studies, 32(4), 447-461.

Eßer, F. (2017). Enacting the overweight body in residential child care: Eating and agency beyond the natureculture divide. Childhood, 24(3), 286-299.

Fader, N., Legg, E., \& Ross, A. (2019). The relation of sense of community in sport on resilience and cultural adjustment for youth refugees. World Leisure Journal, 61(4), 291-302.

Farquharson, K., Spaaij, R., Gorman, S., Jeanes, R., Lusher, D., \& Magee, J. (2019). Managing racism on the field in Australian junior sport. In P. Essed, K. Farquharson, K. Pillay, \& E. J. White (Eds.), Relating worlds of racism: Dehumanisation, belonging and the normativity of European whiteness (pp. 165-189). Cham: Palgrave Macmillan.

Fletcher, T. (2019). Negotiating fatherhood: Sport and family practices. Cham: Palgrave Macmillan.

Fletcher, T., Carnicelli, S., Lawrence, S., \& Snape, R. (2017). Reclaiming the 'L' word: Leisure studies and UK higher education in neoliberal times. Leisure Studies, 36(2), 293-304.

Fowlie, J., Eime, R. M., \& Griffiths, K. (2020). Barriers to adolescent female participation in cricket. Annals of Leisure Research, https://doi.org/10.1080/11745398.2019.1710716.

Fox, K. M. (2000). Echoes of leisure: Questions, challenges, and potentials. Journal of Leisure Research, $32(1), 32-36$.

Friedman, H. L. (2013). Playing to win: Raising children in a competitive culture. Berkeley: University of California Press.

Gill, T. (2007). No fear: Growing up in a risk averse society. London: Calouste Gulbenkian Foundation.

Gill, P. E., \& Persson, M. (2008). On using concept-maps to study school-children's understanding of leisuretime. Leisure Studies, 27(2), 213-220.

Gillis, J. R. (2003). Childhood and family time: A changing historical relationship. In A. Jensen \& L. McKee (Eds.), Children and the changing family: Between transformation and negotiation (pp. 149-164). London: RoutledgeFalmer.

Gordon, D. (2008). Children, policy and social justice. In G. Craig, T. Burchardt, \& D. Gordon (Eds.), Social justice and public policy: Seeking fairness in diverse societies (pp. 157-179). Bristol: Policy Press.

Gouldner, A. W. (1971). The coming crisis of Western sociology. London: Heinemann.

Haglund, B., \& Anderson, S. (2009). Afterschool programs and leisure-time Centres: Arenas for learning and leisure. World Leisure Journal, 51(2), 116-129.

Hays, S. (1996). The cultural contradictions of motherhood. New Haven: Yale University Press.

Henderson, K. A. (1994). Broadening an understanding of women, gender and leisure. Journal of Leisure Research, 26(1), 1-7.

Henderson, K. A. (1996). One size doesn't fit all: The meanings of women's leisure. Journal of Leisure Research, 28(3), 139-154.

Henderson, K. A. (2013). Feminist leisure studies: Origins, accomplishments and prospects. In T. Blackshaw (Ed.), Routledge handbook of leisure studies (pp. 26-39). London: Routledge.

Holder, M. D., Coleman, B., \& Sehn, Z. L. (2009). The contribution of active and passive leisure to children's well-being. Journal of Health Psychology, 14(3), 378-386.

Holloway, S. L., \& Pimlott-Wilson, H. (2014). Enriching children, institutionalizing childhood? Geographies of play, extracurricular activities, and parenting in England. Annals of the Association of American Geographers, 104(3), 613-627.

Holloway, S. L., \& Valentine, G. (2003). Cyberkids: Children in the information age. London: Routledge.

Hylton, K. (2010). How a turn to critical race theory can contribute to our understanding of 'race', racism and anti-racism in sport. International Review for the Sociology of Sport, 45(3), 335-354.

Irving, H. R., \& Giles, A. R. (2011). Examining the child's impacts on single mothers' leisure. Leisure Studies, 30(3), 365-373.

James, A., \& James, A. (2012). Key concepts in childhood studies. London: Sage.

James, A., Jenks, C., \& Prout, A. (1998). Theorizing childhood. Cambridge: Polity.

Jeanes, R. (2010). Seen but not heard? Examining children's voices in leisure and family research. Leisure/ Loisir, 34(3), 243-259.

Jeanes, R., \& Magee, J. (2011). Come on my son! Examining fathers, masculinity and 'fathering through football'. Annals of Leisure Research, 14(2-3), 273-288. 
Jeanes, R., \& Magee, J. (2012). 'Can we play on the swings and roundabouts?': Creating inclusive play spaces for disabled young people and their families. Leisure Studies, 31(2), 193-210.

Jeanes, R., O’Connor, J., \& Alfrey, L. (2015). Sport and the resettlement of young people from refugee backgrounds in Australia. Journal of Sport and Social Issues, 39(6), 480-500.

Jeanes, R., Spaaij, R., Magee, J., Farquharson, K., Gorman, S., \& Lusher, D. (2019). Developing participation opportunities for young people with disabilities? Policy enactment and social inclusion in Australian junior sport. Sport in Society, 22(6), 986-1004.

Jenkins, J. (2009). With one eye on the clock: Non-resident dads' time use, work and leisure with their children. In T. Kay (Ed.), Fathering through sport and leisure (pp. 88-105). London: Routledge.

Juniu, S., \& Henderson, K. (2001). Problems in researching leisure and women: Global considerations. World Leisure Journal, 43(4), 3-10.

Karsten, L., \& Felder, N. (2015). Parents and children consuming the city: Geographies of family outings across class. Annals of Leisure Research, 18(2), 1-14.

Karsten, L., Kamphuis, A., \& Remeijnse, C. (2015). 'Time-out' with the family: The shaping of family leisure in the new urban consumption spaces of cafes, bars and restaurants. Leisure Studies, 34(2), 166-181.

Kay, T. (2007). Fathering through sport. World Leisure Journal, 49(2), 69-82.

Kelly, J. R. (1974). Sociological perspectives and leisure research. Current Sociology, 22(1-3), 127-158.

Kremer-Sadlik, T., Fatigante, M., \& Fasulo, A. (2008). Discourses on family time: The cultural interpretation of family togetherness in Los Angeles and Rome. Ethos, 36(3), 283-309.

Lancy, D. F. (1996). Playing on the mother-ground: Cultural routines for Children's development. New York: Guilford Press.

Lareau, A. (2002). Invisible inequality: Social class and childrearing in black families and White families. American Sociological Review, 67(5), 747-776.

Lareau, A. (2011). Unequal childhoods: Class, race, and family life (2nd ed.). Berkeley: University of California Press.

Lareau, A., \& Weininger, E. (2008). The context of school readiness: Social class difference in time use in family life. In A. Booth \& A. C. Crouter (Eds.), Disparities in school readiness (pp. 155-187). New York: Lawrence Erlbaum Associates.

Lee, N. (2001). Childhood and society: Growing up in an age of uncertainty. Buckingham: Open University Press.

Leonard, M. (2016). The sociology of children, childhood and generation. London: Sage.

Liechty, T., \& Genoe, M. R. (2013). Older men's perceptions of leisure and aging. Leisure Sciences, 35(5), 438-454.

Livingstone, S. (2007). From family television to bedroom culture: Young people's media at home. In E. Devereux (Ed.), Media studies: Key issues and debates (pp. 302-321). London: Sage.

Livingstone, S. (2009). Children and the internet: Great expectations, challenging realities. Cambridge: Polity.

Livingstone, S., \& Helsper, E. J. (2008). Parental mediation of children's internet use. Journal of Broadcasting \& Electronic Media, 52(4), 581-599.

Livingstone, S., Kirwil, L., Ponte, C., \& Staksrud, E. (2014). In their own words: What bothers children online? European Journal of Communication, 29(3), 271-288.

Livingstone, S., Mascheroni, G., \& Staksrud, E. (2018). European research on children's internet use: Assessing the past and anticipating the future. New Media \& Society, 20(3), 1103-1122.

Macdonald, D., Rodger, S., Abbott, R., Ziviani, J., \& Jones, J. (2005). "I could do with a pair of wings": Perspectives on physical activity, bodies and health from young Australian children. Sport, Education and Society, 10(2), 195-209.

Martins, N., Matthews, N. L., \& Ratan, R. A. (2017). Playing by the rules: Parental mediation of video game play. Journal of Family Issues, 38(9), 1215-1238.

Mason, J., \& Bessell, S. (2017). Children's lives: Taking account of the social. Children and Society, 31(4), $257-262$.

Mayall, B. (1998). Towards a sociology of child health. Sociology of Health \& Illness, 20(3), 269-288.

Mayall, B. (2002). Towards a sociology for childhood: Thinking from Children's lives. Buckingham: Open University.

Mayall, B. (2013). A history of the sociology of childhood. London: Institute of Education Press.

Mjaavatn, P. E. (2016). Changes in children's preferences for outdoor activities: A longitudinal study. Leisure/ Loisir, 40(2), 225-244.

Moosa-Mitha, M. (2005). A difference-centred alternative to theorization of children's citizenship rights'. Citizenship Studies, 9(4), 369-388.

Morrow, V. (1996). Rethinking childhood dependency: Children's contributions to the domestic economy. The Sociological Review, 44(1), 58-77.

Moss, P., \& Petrie, P. (2002). From children's services to children's spaces: Public policy, children and childhood. London: RoutledgeFalmer. 
Naftali, O. (2010). Caged golden canaries: Childhood, privacy and subjectivity in contemporary urban China. Childhood, 17(3), 297-311.

Neale, B. (2004). Introduction: Young children's citizenship. In B. Neale (Ed.), Young children's citizenship: Ideas into practice (pp. 6-18). York: Joseph Rowntree Foundation.

Nelson, M. K. (2010). Parenting out of control: Anxious parents in uncertain times. New York: New York University Press.

Opie, I., \& Opie, P. (1969). Children's games in street and playground: Hunting, racing, duelling, exerting, daring, guessing, acting, pretending. Oxford: Clarendon Press.

Oswell, D. (2013). The agency of children: From family to global human rights. Cambridge: Cambridge University Press.

Parr, M. G., \& Schmalz, D. (2019). Leisure studies in the 21st century: Challenges and opportunities in our collective identity. Journal of Leisure Research, 50(4), 372-387.

Passmore, A. (2003). The occupation of leisure: Three typologies and their influence on mental health in adolescence. OTJR: Occupation, Participation and Health, 23(2), 76-83.

Prout, A. (2011). Taking a step away from modernity: Reconsidering the new sociology of childhood. Global Studies of Childhood, 1(1), 4-14.

Prout, A. \& James, A. (1997). A new paradigm for the sociology of childhood? Provenance, prospect and problems. In A. James \& A. Prout (Eds.), Constructing and reconstructing childhood: Contemporary issues in the sociological study of childhood (2nd ed.) (pp. 7-32). London: Falmer Press.

Pugh, A. J. (2009). Longing and belonging: Parents, children, and consumer culture. Berkeley: University of California Press.

Putnam, R. D. (2015). Our kids: The American dream in crisis. New York: Simon \& Schuster.

Quarmby, T., \& Dagkas, S. (2010). Children's engagement in leisure time physical activity: Exploring family structure as a determinant. Leisure Studies, 29(1), 53-66.

Qvortrup, J. (1987). Introduction to sociology of childhood. International Journal of Sociology, 17(3), 3-37.

Qvortrup, J. (2007). Editorial: A reminder. Childhood, 14(4), 395-400.

Reay, D. (2010). Class acts: Parental involvement in schooling. In M. Klett-Davies (Ed.), Is parenting a class issue? (pp. 31-43). London: Family and Parenting Institute.

Reay, D. (2017). Miseducation: Inequality, education and the working classes. Bristol: Policy Press.

Renold, E. (2002). Presumed innocence: (hetero)sexual, heterosexist and homophobic harassment among primary school girls and boys. Childhood, 9(4), 415-434.

Rhoden, S., Hunter-Jones, P., \& Miller, A. (2016). Tourism experiences through the eyes of a child. Annals of Leisure Research, 19(4), 424 443.

Roberts, K. (1983). Youth and leisure. London: Allen \& Unwin.

Roberts, K. (2006). Leisure in contemporary society (2nd ed.). Wallingford: CABI.

Roberts, K. (2013). Sociology of leisure. Sociopedia.isa. https://doi.org/10.1177/205684601371.

Roberts, K. (2015). Social class and leisure during recent recessions in Britain. (2015). Leisure Studies, 34(2), 131-149.

Robertson, B. J. (1999). Leisure and family: Perspectives of male adolescents who engage in delinquent activity as leisure. Journal of Leisure Research, 31(4), 335-358.

Rojek, C. (2005). Leisure theory: Principles and practices. Basingstoke: Palgrave MacMillan.

Rojek, C. (2010). The labour of leisure: The culture of free time. London: Sage.

Rojek, C., Shaw, S. M., \& Veal, A. J. (Eds.). (2006a). A handbook of leisure studies. Basingstoke: Palgrave MacMillan.

Rojek, C., Shaw, S. M., \& Veal, A. J. (2006b). Introduction: Process and content. In C. Rojek, S. M. Shaw, \& A. J. Veal (Eds.), A handbook of leisure studies (pp. 1-21). Basingstoke: Palgrave MacMillan.

Samdahl, M., \& Kelly, J. (1999). Speaking only to ourselves? Citation analysis of journal of leisure research and leisure sciences. Journal of Leisure Research, 31(2), 171-180.

Scott, J. (2000). Children as respondents: The challenge for quantitative methods. In P. Christensen \& A. James (Eds.), Research with children: Perspectives and practices (pp. 98-119). London: Falmer Press.

Sen, H. (2014). 'Time-out' in the land of Apu: childhoods, bildungsmoratorium and the middle classes of urban West Bengal. Wiesbaden: Springer VS.

Shannon, C. S. (2006). Parents' messages about the role of extracurricular and unstructured leisure activities: Adolescents' perceptions. Journal of Leisure Research, 38(3), 398-420.

Shannon, C. S. (2016). Exploring factors influencing girls' continued participation in competitive dance. Journal of Leisure Research, 48(4), 284-306.

Shannon, C. S., \& Shaw, S. M. (2008). Mothers and daughters: Teaching and learning about leisure. Leisure Sciences, 30(1), 1-16. 
Shaw, S. M. (1997). Controversies and contradictions in family leisure: An analysis of conflicting paradigms. Journal of Leisure Research, 29(1), 98-112.

Shaw, S. M. (2000). If our research is relevant, why is nobody listening? Journal of Leisure Research, 32(1), 147-151.

Shaw, S. M. (2008). Family leisure and changing ideologies of parenthood. Sociology Compass, 2(2), 688-703.

Shaw, S. M., \& Dawson, D. (2001). Purposive leisure: Examining parental discourses on family activities. Leisure Sciences, 23(4), 217-231.

Shaw, S. M., Havitz, M. E., \& Delemere, F. M. (2008). "I decided to invest in my kids' memories": Family vacations, memories, and the social construction of the family. Tourism Culture \& Communication, 8(1), 13-26.

Shin, W., \& Huh, J. (2011). Parental mediation of teenagers' video game playing: Antecedents and consequences. New Media \& Society, 13(6), 945-962.

Shin, K., \& You, S. (2013). Leisure type, leisure satisfaction and adolescents' psychological wellbeing. Journal of Pacific Rim Psychology, 7(2), 53-62.

Smart, C., Neale, B., \& Wade, A. (2001). The changing experience of childhood: Families and divorce. Cambridge: Polity.

Snape, R. (2020). Becoming sociological: A brief historical review of leisure in the social survey 1880-1939. International Journal of the Sociology of Leisure, 3(1), 37-51.

Sonck, N., Nikken, P., \& De Haan, J. (2013). Determinants of internet mediation: A comparison of the reports by Dutch parents and children. Journal of Children and Media, 7(1), 96-113.

Spracklen, K. (2009). The meaning and purpose of leisure. Basingstoke: Palgrave Macmillan.

Stebbins, R. A. (1997). Casual leisure: A conceptual statement. Leisure Studies, 16(1), 17-25.

Stebbins, R. A. (2007). Serious leisure. New Brunswick: Transaction Publishers.

Stebbins, R. A. (2018). The sociology of leisure: An estranged child of mainstream sociology. International Journal of the Sociology of Leisure, 1(1), 43-53.

Such, L. (2009). Fatherhood, the morality of personal time and leisure-based parenting. In T. Kay (Ed.), Fathering through sport and leisure (pp. 73-87). London: Routledge.

Sutton-Smith, B. (1997). The ambiguity of play. Cambridge: Harvard University Press.

Swanson, L. (2009). Complicating the "soccer mom". Research Quarterly for Exercise and Sport, 80(2), 345-354.

Swinton, A. T., Freeman, P. A., \& Zabriskie, R. B. (2009). Divorce and recreation: Non-resident fathers' leisure during parenting time with their children. In T. Kay (Ed.), Fathering through sport and leisure (pp. 145-163). London: Routledge.

Symons, K., Ponnet, K., Walrave, M., \& Heirman, W. (2017). A qualitative study into parental mediation of Adolescents' internet use. Computers in Human Behavior, 73, 423-432.

Thorne, B. (1987). Re-visioning women and social change: Where are the children? Gender and Society, 1(1), 85-109.

Thorne, B. (2007). Editorial: Crafting the interdisciplinary field of childhood studies. Childhood, 14(2), 147-152.

Trussell, D. E., Jeanes, R., \& Such, E. (2017). Revisiting family leisure research and critical reflections on the future of family-centered scholarship. Leisure Sciences, 39(5), 385-399.

Vincent, C., \& Ball, S. J. (2007). 'Making up' the middle-class child: Families, activities and class dispositions. Sociology, 41(6), 1061-1077.

Warming, H. (2019). Trust and power dynamics in children's lived citizenship and participation: The case of public schools and social work in Denmark. Children \& Society, 33(4), 333-346.

Well, K. (2017). Childhood studies:Making young subjects. Cambridge: Polity.

Willett, R., Richards, C., Marsh, J., Burn, A., \& Bishop, J. C. (Eds.). (2013). Children, media and playground cultures: Ethnographic studies of school playtimes. Basingstoke: Palgrave Macmillan.

Wyness, M. (2012). Childhood and society (2nd ed.). Basingstoke: Palgrave Macmillan.

Wyness, M. (2018). Children's participation: Definitions, narratives and disputes. In C. Baraldi \& T. Cockburn (Eds.), Theorising childhood (pp. 53-72). Cham: Palgrave Macmillan.

Yuen, F. (2004). "It was fun. . .I liked drawing my thoughts": Using drawings as a part of the focus group process with children. Journal of Leisure Research, 36(4), 461-482.

Yuen, F., Pedlar, A., \& Mannell, R. (2005). Building community and social capital through children's leisure in the context of an international camp. Journal of Leisure Research, 37(4), 494-518.

Zabriskie, R. B., \& McCormick, B. P. (2003). Parent and child perspectives of family leisure involvement and satisfaction with family life. Journal of Leisure Research, 35(2), 163-189.

Zeiher, H. (2011). Institutionalization as a secular trend. In J. Qvortrup, W. A. Corsaro, \& M. Honig (Eds.), The Palgrave handbook of childhood studies (pp. 127-139). Basingstoke: Palgrave Macmillan.

Zelizer, V. A. (1994). Pricing the priceless child: The changing social value of children. Princeton: Princeton University Press.

Publisher's Note Springer Nature remains neutral with regard to jurisdictional claims in published maps and institutional affiliations. 